\title{
The Evolution of Phenolic Compounds in Vitis vinifera L. Red Berries during Ripening: Analysis and Role on Wine Sensory-A Review
}

\author{
Gianluca Allegro (D), Chiara Pastore *, Gabriele Valentini and Ilaria Filippetti
}

check for

updates

Citation: Allegro, G.; Pastore, C.; Valentini, G.; Filippetti, I. The Evolution of Phenolic Compounds in Vitis vinifera $\mathrm{L}$. Red Berries during Ripening: Analysis and Role on Wine Sensory-A Review. Agronomy 2021, 11, 999. https://doi.org/10.3390/ agronomy11050999

Academic Editor:

Salvatore Camposeo

Received: 12 April 2021

Accepted: 15 May 2021

Published: 18 May 2021

Publisher's Note: MDPI stays neutral with regard to jurisdictional claims in published maps and institutional affiliations.

Copyright: (c) 2021 by the authors. Licensee MDPI, Basel, Switzerland. This article is an open access article distributed under the terms and conditions of the Creative Commons Attribution (CC BY) license (https:// creativecommons.org/licenses/by/ $4.0 /)$.
Department of Agricultural and Food Sciences, University of Bologna, viale G. Fanin 44, 40127 Bologna, Italy; gianluca.allegro2@unibo.it (G.A.); gabriele.valentini4@unibo.it (G.V.); ilaria.filippetti@unibo.it (I.F.)

* Correspondence: chiara.pastore@unibo.it

\begin{abstract}
The study of phenolic maturity in Vitis vinifera L. requires a multidisciplinary approach to understand how the evolution of berry flavonoids and cell wall material influence the colour and the textures of red wine. This is a challenging issue which involves researchers of viticulture and enology, and the results of their work are of particular interest for the producers of high-quality red wines. This review reports the current knowledge regarding phenolic maturity, describing the sensorial traits of the different compounds, the evolution of berry flavonoids and the methodologies used to evaluate their characteristics. Finally, the role of cell wall material in influencing the extractability of anthocyanins and proanthocyanidins was shown. By means of a critical review of the results, it can be hypothesised that prolonged ripening improved colour characteristics and mouthfeel properties, thanks to the higher amounts of extractable skin flavonoids associated with lower amounts of seed proanthocyanidins, and to the increased affinity of the cell wall material for the proanthocyanidins most involved in the perception of unpleasant astringency.
\end{abstract}

Keywords: anthocyanins; astringency; berry ripening; bitterness; cell wall material; extractability; phenolic maturity; proanthocyanidins

\section{Introduction}

It is well known that cultivar, meso and micro-climate, nutritional status, water availability and cultural practices have a significant effect on ripening and on the final chemical composition of Vitis vinifera L. berries. Moreover, maturity range can be affected by the desired wine style. The evolution of soluble solid concentration, $\mathrm{pH}$ and titratable acidity are measured during ripening to predict the main technological parameters of wine, such as alcohol content, $\mathrm{pH}$ and total acidity, and represent a basic grape ripening assessment; however, information regarding skin and seed phenolic compounds are key determinants for the production of high-quality red wines.

Considering the role that phenolic maturity of red-berry grapevine cultivars plays on grape quality, the aim of the current work was to review the current knowledge regarding this issue and to describe the changes that flavonoids undergo during ripening, and their effects on wine colour and textures.

\subsection{Classification of Berry Flavonoids}

The most representative classes of berry flavonoids are constituted by anthocyanins and flavanols. Anthocyanins accumulate in the skin of red berries starting from veraison; they are present as glucoside derivatives of delphinidin, cyanidin, petunidin, peonidin and malvidin [1]. Catechin, epicatechin, epicatechin-gallate and epigallocatechin are flavanols present from fruit set in berry skins and seeds as free monomers and polymeric forms, which are called proanthocyanidins (PAs) or tannins [2]. Skin PAs have a higher mean degree of polymerisation $(\mathrm{mDP})$ and a lower proportion of galloylated forms as 
compared to those of seeds, while epigallocatechin is not found in seed flavanols. Thus, the epigallocatechin and epicatechin-gallate found in wine may indicate the berry tissue, skin or seed from which the PAs are extracted [3].

\subsection{Role of Anthocyanins and Flavanols in Determining Wine Quality}

The importance of each class of berry flavonoids to wine quality has been known for a long time. Anthocyanins are pigments responsible for red wine colour, and their contribution could be direct, due to their spectral properties, or indirect after copigmentation reaction with other phenolic compounds, such as flavonols which are present in minor quantities with respect to other flavonoids [4]. During wine ageing, the formation of pigmented polymers, resulting from the reaction between anthocyanins and PAs, modulates wine colour which shifts to a red-brown tint [5]. Colour has been widely recognised as a good predictor of red wine quality; Jackson and co-workers [6] and Parpinello and co-workers [7] have shown that higher overall quality, evaluated after a complete sensory assessment, was associated with higher colour intensity, for Beaujolais and Novello wines, respectively; similar results were found in a study conducted on young red wines from South Australia [8].

Anthocyanins, falavan-3-ol monomers and PAs contribute to the perception of important mouthfeel attributes (i.e., astringency and bitterness) and to the overall quality of the wine $[9,10]$. In this context, Mercurio and co-workers [11] reported that Australian Cabernet Sauvignon and Shiraz wines with a higher concentration of total phenolic compounds were allocated to grades with higher market value and, in the companion paper, the increase in projected bottle price in relation to the increase in colour density, tannin concentration and tannin mDP was observed [12]. Moreover, a study conducted on premium red wines from different Spanish Denominations of Origin, described a positive relationship between the overall quality, and the concentrations of the malvidin-catechin dimer and of the PAs linked to polysaccharides [13].

\subsection{Relationship between Flavonoid Composition and Mouthfeel Attributes of Wine}

Although the relationship between the concentration of flavonoids and wine quality has been proved, it is important to note that the composition of these compounds could also alter the perception of the mouthfeel attributes. Astringency, in particular, can define the quality, complexity and persistence of a red wine better than other sensorial traits [14], and it is well known that a balanced level of astringency is a key component of highquality red wines [15]. Gawel and co-workers [16] have described this very complex oral sensation with thirty-three different sub-qualities which were grouped into two 'pleasant' categories (complex and surface smoothness) and five 'unpleasant' categories (drying, harsh, unripe, dynamic, particulate). Although the majority of the astringency sensations can be considered undesirable, a study conducted on different red Italian wines has indicated that 'unpleasant' astringency, if well balanced, could also enhance wine quality, as found in premium Nebbiolo and Sangiovese wines [17].

Several studies have been conducted to describe the oral sensations of different flavonoids by tasting phenolic fractions or analysing the sensory properties of wines with different phenolic compositions. The results of these studies are herein presented.

\subsubsection{Sensory Analyses of Flavonoid Fractions}

The sensory analysis of flavan-3-ol monomers, dimers and trimers dissolved in aqueous ethanol $(1 \% v / v)$ indicated that astringency increased with the degree of polymerisation while bitterness decreased [18]; however, more recent research regarding PA fractions isolated from Italian and Spanish red wines has showed that monomers and dimers contribute slightly to astringency [19] and to bitterness [10]. Vidal and co-workers [20] also found that the polymer length of the PA fractions was positively correlated with astringency and with some 'unpleasant' sub-qualities; however, the mDP did not influence bitterness. Moreover, the same author reported that a higher percentage of galloylation elicited rougher astrin- 
gent attributes while epigallocatechin units slightly decreased those sensations. The PA fractions of Cabernet franc skin and seed were equally astringent [21], probably due to the equivalent contributions of the high $\mathrm{mDP}$ of the skin PAs and the high percentage of galloylation of the seed PAs. Conversely, seed PA extracts of Aglianico grapes were more astringent than those of the skin [22].

Some studies have been conducted involving the addition of flavonoids to acidified water or to commercial wines, and it was noted that epicatechin was more astringent and bitter than catechin [23]. Moreover, it should be noted that the concentration of PAs may prevail in the perception of astringency rather than the structural composition of the above-mentioned compounds [24].

In the literature, there is consensus regarding the role of anthocyanins in influencing mouthfeel attributes. These pigments are per se less astringent than PA; however, when added to wine, they can increase 'pleasant' astringency and the perception of fullness [10,21,25].

\subsubsection{Sensory Characteristics of Flavonoids in Wine}

The results of the studies based on wine sensory analysis appear to be in accord with the many findings observed by the sensory evaluations of phenolic fractions. As reported by Preys and co-workers [26] in a study conducted on 61 French and 60 German red wines, the higher the concentration of PAs, the galloylation rate and the $\mathrm{mDP}$, the higher the astringency. On the contrary, perceived astringency was lowered by a higher concentration of epigallocatechin [26,27]. Considering these results, the higher amount of epigallocatechin found in Carménère wines, as compared to that of Cabernet Sauvignon, may explain the lower astringency of the former, although it was characterised by the higher content of PAs of a higher mDP [28]. In Shiraz wines, the 'unpleasant' pucker astringency was positively correlated with the concentration of PAs and pigmented polymers, but negatively correlated with the concentration of anthocyanins [29]. Thus, the concentration of seed-derived PAs and that of total phenolic compounds in Cabernet Sauvignon wines were positively associated with astringency and bitterness [30]. Finally, some studies conducted on Tannat wines, which are usually characterised by high levels of phenolic compounds, have described that wines with similar overall astringency differed significantly in 'unpleasant' sub-qualities [31], and that PA concentration was positively correlated to aggressive astringency and negatively to soft textures [32].

Considering the results described in this section, it would appear that high-quality red wines are marked by high colour intensity and balanced astringency, which should be mainly characterised by 'pleasant' sub-qualities. According to the previously reported studies, these properties may be conferred by anthocyanins and skin Pas, while seed PAs may be considered undesirable from a winemaking perspective [33]. Accordingly, Ristic and co-workers [34] described that the index Anthocyanins x Skin PAs/Seed PAs, calculated with the relative concentrations in grapes, was highly correlated with the "overall quality" of the resulting wines.

The interpretation of these results allowed the authors to speculate that the appropriate berry phenolic maturity for the production of a high-quality red wine might be that condition in which anthocyanins and PAs could easily be extracted from the skin while low quantities of flavanols were released by seeds. This condition is affected by many factors which are subject to changes during ripening, such as the concentration, composition and extractability of flavonoids, and the activity of other berry compounds (i.e., skin and flesh cell wall material) which interact with flavonoids.

In the following sections, the methodologies applied to estimating the phenolic maturity and the results of the studies aimed at evaluating the properties of flavonoids and cell wall material are reported.

\section{Methods Used to Determine Phenolic Maturity}

Determination of the phenolic maturity implies the extraction of phenolic compounds from berries and the measurement of their concentrations. Phenolic extracts can be obtained 
from grapes using different solvents and, after their extraction, methods of analysis could include evaluation of the total content spectrophotometrically or separation using high performance liquid chromatography (HPLC). The main methods used for analysing the phenolic maturity are described below.

\subsection{Colorimetric Assays}

The phenolic content of berries has been determined colourimetrically using FolinCiocalteau reagent for a long time [35]. The extraction of polyphenolic compounds is performed on berry homogenate or on ground tissues, using methanol [36] or acidified methanol [37]. The following quantification is based on a standard curve of gallic acid [38]. Colourimetric analysis determines the total amounts of polyphenols giving any information regarding colour characteristics and the different sub-qualities of astringency.

Another colourimetric assay, aimed at quantifying flavanol concentration in berries and wines, was proposed by Deshpande and co-workers [39]: grape extracts were mixed with vanillin $1 \%$ methanol and incubated with sulfuric acid ( $25 \% v / v$ methanol) before spectrophotometric measurements. This protocol was modified by Sun and co-workers [40] in order to ameliorate its reproducibility. Similarly, flavanol can be quantified after the reaction with p-dimethylaminocinnamaldehyde (DMCA), as described by McMurrough and McDowell [41]. This procedure was successively optimised for grape extracts and wine by Nagel and Glories [42], and it showed higher specificity than a vanillin assay [43].

\subsection{Methods Involving the Precipitation of Flavanols}

Specific protocols for the assessment of flavanols are based on the ability of different proteins to precipitate these compounds. Considering that astringency is caused by a reduction in oral lubrification due to the interaction between flavanols and salivary proteins, these methods may give more specific information regarding phenolic maturity.

Hagerman and Butler [44] determined plant-derived PAs after their precipitation with bovine serum albumin (BSA) and reaction with ferric chloride. This procedure was adapted to grapevine berry analysis to evaluate skin and seed contribution separately after the extraction of PAs using a solution containing acetone [45] or aqueous ethanol [46].

Gelatine, similar to human saliva, contains proline-rich proteins and is profitably used to determine the concentration of PAs in wine and its astringency [47-49] but is rarely used for skin and seed extracts [50]. Whole human saliva showed interesting results in the characterisation of the astringency of skin and seed extracts [22,51]; however, the heterogeneity of this precipitating agent has limited the use of this technique.

Sarnekis and co-workers [52] proposed a protocol for the quantification of grape PAs by precipitation using the methyl cellulose precipitable (MCP) assay after berry homogenisation and extraction in aqueous ethanol. The results obtained with this method are highly correlated with wine astringency such as those using proteins as precipitation agent and, thanks to its simplicity, it also appears suitable for wineries [53].

\subsection{The Glories Method and the Following Modifications}

A specific method for assessing berry phenolic maturity is based on the determination of the total amount of flavonoids and of the portion which can be extracted during the winemaking process [54,55]. Phenolic compounds are extracted from berry homogenates in acidified ethanol ( $\mathrm{pH} 1.0)$ to quantify their total amount, and in a solution at $\mathrm{pH} 3.2$ to evaluate the extractable portion. The concentrations of anthocyanins and flavanols are then usually determined using spectrophotometric analysis [56,57]. This method, easy to apply in the laboratory, enhances knowledge of the characteristics of berry flavonoids thanks to the characterisation of their extractability (i.e., the ratio between the extractable portion and the total amount), and makes it easier to establish the most suitable time for harvest. Nevertheless, since the analysis of flavanols is conducted on berry homogenates, it is not possible to determine the contribution of skin and seed flavanols and, as a consequence, some information regarding the prediction of astringency, due to the origin of the phenolic 
compounds, may be lost. Moreover, the disruption of skin and seed tissues following homogenisation might mislead the evaluation of anthocyanin extractability which is normally affected by the slow degradation of the skin cell wall.

As reported by Nadal [58], protocols were developed by modifying the Glories method; the composition and the $\mathrm{pH}$ of the solutions were changed by Peyron [59] and Mateos [60], respectively, while Lamadon [61] proposed using only one extracting solution containing $15 \% v / v$ of ethanol.

\subsection{Methods for the Determination of Flavonoid Concentration and Composition}

The characterisation of the total amount of berry flavanols requires exhaustive extraction of skin and seed powders in a solution using $70 \%$ acetone $[2,62]$ or in a solution using $50 \%$ ethanol, even if the latter showed lower extraction efficiency than acetone [63]. High performance liquid chromatography carried out after the acid-catalysed cleavage of the PAs then allows quantification of the constitutive units of the flavanols and calculation of the $\mathrm{mDP}$ of the polymeric forms, increasing the accuracy of the information regarding the properties of these compounds. The cleavage of PAs may be carried out in the presence of excess phloroglucinol [64] or with thiolysis reactions $[65,66]$. It is worth noting that the results obtained with these methods, as with those based on protein precipitation, were highly correlated with the perceived astringency, while the results of colorimetric analysis, being nonspecific assays, showed a very low correlation coefficient [67]. Furthermore, in a comparison between the protocols proposed by Iland et al. [62] and Glories [54], the former showed the best correlation with wine data [68].

Other methods based on gel permeation chromatography (GPC) and size-exclusion chromatography (SEC) may be employed to evaluate the molecular mass of grape and wine flavanols [69,70]; however, they do not give information regarding their composition [71].

Determination of the total amount of anthocyanins can also be carried out using HPLC, and the exhaustive extraction of skin, or skin homogenates, can be carried out in methanol [72,73], acidified methanol [74-76], aqueous methanol [77], acidified ethanol [78] or aqueous acidified ethanol [62].

The same HPLC analysis can be carried out on the extractable portion of the flavonoids in order to obtain information regarding the quantity of anthocyanins and flavanols which can be effectively released during vinification. In this case, the skins and the seeds are soaked separately in model hydroalcoholic solutions characterised by an ethanol concentration and $\mathrm{pH}$ similar to that of wine for a duration varying from $5 \mathrm{~h}$ to 21 days [1,79-81]. In addition, some methods have been designed to mimic the increase in ethanol due to the fermentation and the temperature at which this biological process proceeds [82-84].

The use of wine-like extractant solutions has been proven to be effective in predicting the concentration of a wine's flavanols [85]; this approach can also be aimed at evaluating flavonoid extractability during ripening, a characteristic which behaves differently depending on the berry tissue (i.e., skin and seeds).

\subsection{Other Methods}

Some methods based on texture analysis have showed that the mechanical properties of berries, in particular the skin break force, are highly correlated with phenolic compound concentration and extractability, proving to be powerful tools in the study of phenolic maturity [86-89].

Moreover, non-destructive analyses have been proposed to estimate the concentration of soluble solids and phenolic compounds, using a fluorescence method [90] or near infrared hyperspectral images [91]. After additional investigation and cultivar-based calibration curves, these procedures could be adopted for the fast and inexpensive monitoring of berry characteristics, which would be useful in establishing the harvest period and the quality of different lots of grapes with the objective of a precision viticulture approach.

Finally, considering that the change in colour of the seed coat was a good indicator of berry flavonoid properties [92], since a darker colour corresponded to higher antho- 
cyanin extractability and lower percentages of seed flavanols [93], advanced methods were developed to assess phenolic maturity by the elaboration of seed images [94,95].

\section{Evolution of Phenolic Compounds during Berry Ripening}

\subsection{Characteristics of the Total Amount of Skin and Seed Flavonoids}

Considering the key role that the characteristics of anthocyanins and flavanols play on wine quality, many studies have been conducted to determine the evolution of these compounds during berry ripening in order to predict the optimal harvest time for the desired oenological aim. Evidently, the evolution of the characteristics of these compounds is affected by genotype and several environmental factors; however, it is possible to outline the main features.

Anthocyanins in grape berries are synthesised via the flavonoid pathway. All the structural genes involved in anthocyanin biosynthesis are located on the endoplasmic reticulum membranes or in the cytoplasm in which the anthocyanins are directly produced. Almost all the anthocyanins are then stored in the vacuoles. The accumulation of skin anthocyanins in red grape varieties begins with veraison and reaches its maximum in the latest phases of berry ripening when the synthesis decreases or stops [96]. In general, skin anthocyanins accumulate linearly from veraison to harvest; however, in the case of excessively high temperatures, a decline could occur after an initial increase $[78,97]$. The trend of accumulation, in which derivatives of cyanidin were more promptly synthesised at the very early stage of veraison, is relatively common in grapevines, even for cultivars whose anthocyanin profile is largely composed of malvidin and tri-substituted anthocyanins at harvest [98]. Glycosylation, methylation and acylation are necessary for anthocyanin stabilisation and transport into the vacuole. Glycosylation is an important modification for increasing the hydrophilicity and stability of anthocyanins which occurs after veraison in grapevines. Cyanidin 3-glucoside and delphinidin 3-glucoside may also be methylated to be converted to peonidin 3-glucoside and petunidin, or malvidin 3-glucoside, respectively. The acylation of anthocyanins leads to the production of 3-O-acetyl-, 3-O-coumaroyl- and 3-O-caffeoyl-monoglucosides by attaching acyl groups to the C6" position of the glucose moiety [99]. The acylation of anthocyanins occurs from veraison to harvest; however, some cultivars, such as Pinot Noir, do not produce acylated anthocyanins [100].

Flavanols are synthesised in skin and seeds from berry-set to veraison [101]. As a consequence, the concentration of these compounds is highest at the onset of ripening and may subsequently decrease due to berry expansion and the oxidative crosslinking of the polymers [102]. These reactions determine the change in colour of the outer integument of the seed, which turns from yellow into dark-brown [92,103].

The reduction in flavanol concentration after veraison may initially be rapid and can then be followed by a plateau in the last weeks before harvest $[84,104]$ or may not proceed with a specific trend $[2,45,105-107]$.

A steady decrease in flavan-3-ol monomers throughout ripening was observed in the seeds of Cabernet Sauvignon, Syrah (also known as Shiraz), Pinot Noir and Sangiovese $[84,102,106,108]$. Moreover, a reduction in the galloylated forms of seed flavanols until the time of harvest has been reported [109-111] and, in some cases, also of their mDP $[102,106,108,109]$. Considering skin flavanols, Kennedy and co-workers [112,113] observed an increase in epigallocatechin percentage during ripening, as well as an increase in their mDP.

Analysing total skin and seed flavonoids throughout ripening showed them to be good predictors of wine colour characteristics, but they were poorly correlated with wine flavanols and their sensory traits, probably because the evolution of the extractability of these compounds differed between skin and seed [114,115]. As a consequence, as regards the concentration and composition of total skin and seed flavanols, there may be a lack of information useful in assessing the phenolic maturity of grapes [116]. However, the use of hydroalcoholic solutions for the extraction of flavonoids enables the acquiring of more 
realistic information about the concentration and composition of the anthocyanins and flavanols which could be extracted during the maceration of black grapes.

\subsection{Characteristics of the Extractable Portion of Skin and Seed Flavonoids}

Studies based on the extraction of intact skins in wine-like solutions have showed that the concentration of extractable anthocyanins and skin PAs increased during ripening, even if the total amount of these compounds remained constant or even decreased [1,82,84,117-119]. Contrasting behaviour was observed with extractions conducted on ground skins of Cabernet Sauvignon and Carménère [120]. Moreover, homogenised Monastrell skins released lower amounts of extractable anthocyanins with the progression of ripening; however, the wine produced with riper grapes showed the highest colour intensity [121]. Considering these contrasting results, it appears that analysing the evolution of the extractable flavonoids on ground or homogenised skins may lead to incorrect results, as the mechanical disruption of skin tissues may overcome the effect of the cell wall degradation which occurs during ripening [122] and which modulates the effective release of phenolic compounds [86].

Conversely, the seed flavanols extracted under wine conditions are reported to decrease during ripening $[82,84,123]$, following the progressive hardening of the seed coat due to lignification [92,103].

The composition of the extractable flavonoids did not show substantial changes during ripening, except for the monomeric epicatechin-gallate of Monastrell seed which decreased after veraison and was no longer detected beginning a month before the harvest and onwards [123]. Finally, the mean degree of polymerisation of skin and seed PAs did not change with the progression of ripening [82].

The astringency of skin and seed extracts, assessed using ovoalbumin as a precipitation agent, was lower at harvest [117], even when the extractable flavanols were higher than those at the previous sampling date [82]. The latter finding led to the hypothesis that other berry constituents might markedly affect the perception of astringency and, consequently, also the progression of phenolic maturity.

\section{Role of the Cell Wall Material of Flesh and Skin in Phenolic Maturity \\ 4.1. Characterisation and Evolution of the Cell Wall Material Constituents}

In the berry, the structure of flesh (mesocarp) and skin (exocarp) tissues is maintained by the cell wall, which is composed of cellulosic microfibrils, hemicelluloses, pectins, lignin and structural proteins. Polysaccharides may account for $90 \%$ of the cell wall material (CWM) while the remaining $10 \%$ is mainly represented by proteins [124]; however, it is important to note that the composition of CWM varies broadly according to the cultivar [125]. Flesh contains higher concentrations of pectic polysaccharides and proteins than skin [126]; however, it has been reported that up to $75 \%$ of the whole berry CWM might be recovered in the skin [127].

During ripening, changes occur to polysaccharides, such as the solubilisation of pectins which determines berry softening $[128,129]$ and simultaneously, the turnover of proteins determines the drastic increase in hydroxyproline-rich proteins, such as extensins, which may contribute to maintaining the structure of the cell wall, counteracting the ongoing loosening of the berry tissues $[122,126]$.

\subsection{Interactions between the CWM and PAs}

The modifications which occur to the skin and flesh CWM from veraison to harvest have important technological implications as the CWM interacts with phenolic compounds, in particular PAs, modulating their extractability and their precipitation during vinification.

It is well known that PAs may be bound by the CWM via hydrogen bonds and hydrophobic interactions [130]; between the CWM constituents, proteins showed the highest binding capacity $[126,131]$. Considering the polysaccharides, pectins showed higher affinity for PAs than hemicellulose $[132,133]$ while weak interactions were found with cellulose [134]. Comparing the binding capacity of the CWM of different varieties, that 
of Syrah, which is characterised by the lowest amount of pectins, retained lower quantities of PAs than Cabernet Sauvignon and Monastrell [135].

The ability of the CWM to bind PAs increases with the molecular weight and the percentage of galloylation [134] as larger polymers and the galloylated forms present more reactive sites which allow the associations [136-138].

Studies in which the same amount of flesh and skin CWM were combined with PAs of different varieties showed that flesh CWM has the ability to bind a higher quantity of PAs as compared to that of skin $[139,140]$, and also that flesh CWM interacts selectively with high molecular mass PAs while skin CWM showed lower affinity for those compounds [141,142].

The effect of ripening on the properties of the CWM is different between flesh and skin; flesh CWM did not display any changes in its binding capacity during ripening while skin CWM showed the highest affinity for PAs at harvest, in particular for those of higher molecular mass and for the galloylated forms $[143,144]$. The variation of skin CWM binding capacity may be linked to the increase in porosity of the skin cell wall which allows the incorporation of larger molecules [143], and also with the increase or the turnover of protein which determines the accumulation of hydroxyproline in the skin cell wall [145].

Therefore, with the progression of ripening, skin CWM seems to be responsible for limiting the extraction of those compounds which, more than others, elicit the negative sub-qualities of astringency [144].

Finally, it appeared that the CWM interacted with PAs in two ways during vinification; skin CWM, binding these phenolic compounds, reduced their extraction from the berry while flesh CWM, which is easily released in the fermenting wine, may remove PAs of higher molecular mass by precipitation [146].

\subsection{Interactions between CWM and Anthocyanins}

The extraction of anthocyanins was mainly limited by ionic interactions with pectins of CWM [147] while proteins showed a lower binding capacity [148]. Moreover, the affinity of the CWM for acylated anthocyanins was slightly higher than that for nonacylated anthocyanins [147]. These results may explain the differences in the anthocyanin extractability found between varieties characterised by different CWM compositions [149] and also the difficulty in extracting anthocyanin from grapes characterised by both the elevated concentration of anthocyanins and high quantities of skin CWM [150,151]. Finally, Bautista-Ortín and co-workers [152] reported that anthocyanins may lessen the CWM adsorption site to PAs, increasing their extractability.

\section{Conclusions}

The phenolic maturity of Vitis vinifera L. has been studied for a long time so as to understand how the changes occurring to the berries during ripening may affect wine colour and textures. In order to achieve this goal, researchers in many areas of the wine sector have participated in this effort; in fact, as seen in this review, contributions have come from experts in berry ripening physiology, winemaking procedures, wine chemistry and sensory analysis.

Thanks to their work, some key features of phenolic maturity can be outlined:

- anthocyanins contribute to wine colour and may have beneficial effects on astringency;

- skin flavanols mainly contribute to 'pleasant' astringency while seed flavanols contribute to 'unpleasant' astringency;

- extractable skin flavonoids usually increase during ripening (irrespective of the evolution of their total amount) while that of seeds decreases;

- cell wall material affects the presence of anthocyanins and proanthocyanidins in wine, by limiting their extraction and enhancing their precipitation into the wine;

- the affinity of skin CWM for high molecular mass proanthocyanidins and for the galloylated forms increases during ripening; 
- the use of hydroalcoholic solutions gives the most reliable results for a comprehensive evaluation of anthocyanin and flavanol extractability; however, these methodologies cannot be routinely applied in wineries;

- $\quad$ protein-precipitation methods are easy to carry out and give good results in the prediction of astringency.

As a concluding remark, it came to light that the optimal phenolic maturity for the production of high-quality red wines could be achieved by prolonged ripening as the amounts of extractable anthocyanins and proanthocyanidins of skin would be higher, and the concentration of seed flavanols would be lower. Moreover, the CWM would selectively reduce the presence of those proanthocyanidins more involved in the perception of 'unpleasant' astringency.

Author Contributions: Conceptualisation, G.A.; investigation and resource collection, G.A., C.P. and G.V.; writing — review and editing, G.A., C.P. and I.F.; supervision, I.F. All authors have read and agreed to the published version of the manuscript.

Funding: This research received no external funding.

Conflicts of Interest: The authors declare no conflict of interest.

\section{References}

1. Fournand, D.; Vicens, A.; Sidhoum, L.; Souquet, J.M.; Moutounet, M.; Cheynier, V. Accumulation and extractability of grape skin tannins and anthocyanins at different advanced physiological stages. J. Agric. Food Chem. 2006, 54, 7331-7338. [CrossRef]

2. Downey, M.O.; Harvey, J.S.; Robinson, S. Analysis of tannins in seeds and skins of Shiraz grapes throughout berry development. Aust. J. Grape Wine Res. 2003, 9, 15-27. [CrossRef]

3. Cheynier, V.; Dueñas-Paton, M.; Salas, C.; Maury, E.; Souquet, J.M.; Sarni-Manchado, P.; Fulcrand, H. Structure and properties of wine pigments and tannins. Am. J. Enol. Vitic. 2006, 57, 298-305.

4. Boulton, R. The copigmentation of anthocyanins and its role in the color of red wine: A critical review. Am. J. Enol. Vitic. 2001, 52, 67-87.

5. Hayasaka, Y.; Kennedy, J.A. Mass spectrometric evidence for the formation of pigmented polymers in red wine. Aust. J. Grape Wine Res. 2003, 9, 210-220. [CrossRef]

6. Jackson, M.G.; Timberlake, C.F.; Bridle, P.; Vallis, L. Red wine quality: Correlations between colour, aroma and flavour and pigment and other parameters of young Beaujolais. J. Sci. Food Agric. 1978, 29, 715-727. [CrossRef]

7. Parpinello, G.P.; Versari, A.; Chinnici, F.; Galassi, S. Relationship among sensory descriptors, consumer preference and color parameters of Italian Novello red wines. Food Res. Int. 2009, 42, 1389-1395. [CrossRef]

8. Somers, T.C.; Evand, M.E. Wine quality: Correlations with colour density and anthocyanin equilibria in a group of young red wines. J. Sci. Food Agric. 1974, 25, 1369-1379. [CrossRef]

9. Kennedy, J.A.; Saucier, C.; Glories, Y. Grape and wine phenolics: History and perspective. Am. J. Enol. Vitic. 2006, 57, 239-248.

10. Gonzalo-Diago, A.; Dizy, M.; Fernández-Zurbano, P. Contribution of low molecular weight phenols to bitter taste and mouthfeel properties in red wines. Food Chem. 2014, 154, 187-198. [CrossRef]

11. Mercurio, M.D.; Dambergs, R.G.; Cozzolino, D.; Herderich, M.J.; Smith, P.A. Relationship between red wine grades and phenolics. 1. Tannin and total phenolics concentrations. J. Agric. Food Chem. 2010, 58, 12313-12319. [CrossRef] [PubMed]

12. Kassara, S.; Kennedy, J.A. Relationship between red wine grade and phenolics. 2. Tannin composition and size. J. Agric. Food Chem. 2011, 59, 8409-8412. [CrossRef]

13. Saenz-Navajas, M.P.; Tao, Y.S.; Vicente-Ferreira, M.D.; Fernandez-Zurbano, P. Relationship between nonvolatile composition and sensory properties of premium spanish red wines and their correlation to quality perception. J. Agric. Food Chem. 2010, 58, 12407-12416. [CrossRef] [PubMed]

14. Cheynier, V.; Sarni-Manchado, P. Wine Taste and Mouthfeel. In Managing Wine Quality, 1st ed.; Reynold, A., Ed.; Woodhead Publishing Limited: Cambridge, UK, 2010; pp. 29-72.

15. Gawel, R. Red wine astringency: A review. Aust. J. Grape Wine Res. 1998, 4, 74-95. [CrossRef]

16. Gawel, R.; Oberholster, A.; Francis, I.L. A 'Mouth-feel Wheel': Terminology for communicating the mouth-feel characteristics of red wine. Aust. J. Grape Wine Res. 2000, 6, 203-207. [CrossRef]

17. Piombino, P.; Pittari, E.; Gambuti, A.; Curioni, A.; Giacosa, S.; Mattivi, F.; Parpinello, G.P.; Rolle, L.; Ugliano, M.; Moio, L. Preliminary sensory characterisation of the diverse astringency of single cultivar Italian red wines and correlation of sub-qualities with chemical composition. Aust. J. Grape Wine Res. 2020, 26, 233-246. [CrossRef]

18. Peleg, H.; Gacon, K.; Schlich, P.; Noble, A.C. Bitterness and astringency of flavan-3-ol monomers, dimers and trimers. J. Sci. Food Agric. 1999, 79, 1123-1128. [CrossRef]

19. Hufangel, J.C.; Hoffman, T. Orosensory-directed identification of astringent mouthfeel and bitter-tasting compounds in red wine. J. Agric. Food Chem. 2008, 56, 1376-1386. [CrossRef] 
20. Vidal, S.; Francis, L.; Guyot, S.; Marnet, N.; Kwiatkowski, M.; Gawel, R.; Cheynier, V.; Waters, E.J. The mouth-feel properties of grape and apple proanthocyanidins in a wine-like medium. J. Sci. Food Agric. 2003, 83, 564-573. [CrossRef]

21. Brossaud, F.; Cheynier, V.; Noble, A.C. Bitterness and astringency of grape and wine polyphenols. Aust. J. Grape Wine Res. 2001, 7, 33-39. [CrossRef]

22. Gambuti, A.; Rinaldi, A.; Pessina, R.; Moio, L. Evaluation of aglianico grape skin and seed polyphenol astringency by SDS-PAGE electrophoresis of salivary proteins after the binding reaction. Food Chem. 2006, 97, 614-620. [CrossRef]

23. Ferrer-Gallego, R.; Hernández-Hierro, J.M.; Rivas-Gonzalo, J.C.; Escribano-Bailón, M.T. Sensory evaluation of bitterness and astringency sub-qualities of wine phenolic compounds: Synergistic effect and modulation by aromas. Food Res. Int. 2014, 62, 1100-1107. [CrossRef]

24. Gonzalo-Diago, A.; Dizy, M.; Fernández-Zurbano, P. Taste and mouthfeel properties of red wines proanthocyanidins and their relation to the chemical composition. J. Sci. Food Agric. 2013, 61, 8861-8870. [CrossRef]

25. Vidal, S.; Francis, l.; Williams, P.; Kwiatkowski, M.; Gawel, R.; Cheynier, V.; Waters, E. The mouth-feel properties of polysaccharides and anthocyanins in a wine like medium. Food Chem. 2004, 85, 519-525. [CrossRef]

26. Preys, S.; Mazerolles, G.; Courcoux, P.; Samson, A.; Fischer, U.; Hanafib, M.; Bertrand, D.; Cheynier, V. Relationship between polyphenolic composition and some sensory properties in red wines using multiway analyses. Anal. Chim. Acta 2006, 563, 126-136. [CrossRef]

27. Quijada-Morín, N.; Regueiro, J.; Simal-Gandara, J.; Tomas, E.; Rivas-Gonzalo, J.C.; Escribano-Bailon, M.T. relationship between the sensory-determined astringency and the flavanolic composition of red wines. J. Agric. Food Chem. 2012, 60, 12355-12361. [CrossRef] [PubMed]

28. Fernández, K.; Kennedy, J.A.; Agosin, E. Characterization of Vitis vinifera L. cv. Carménère Grape and wine proanthocyanidins. J. Agric. Food Chem. 2007, 55, 3675-3680. [CrossRef] [PubMed]

29. Gawel, R.; Francis, L.; Waters, E.J. Statistical correlations between the in-mouth textural characteristics and the chemical composition of Shiraz wines. J. Agric. Food Chem. 2007, 55, 2683-2687. [CrossRef] [PubMed]

30. Casassa, L.F.; Larsen, R.C.; Beaver, C.W.; Mireles, M.S.; Keller, M.; Riley, W.R.; Smithyman, R.; Harbertson, J.F. Sensory impact of extended maceration and regulated deficit irrigation on Washington State Cabernet Sauvignon wines. Am. J. Enol. Vitic. 2013, 64, 505-514. [CrossRef]

31. Vidal, L.; Antúnez, L.; Giménez, A.; Medina, K.; Boido, E.; Ares, G. Dynamic characterization of red wine astringency: Case study with Uruguayan Tannat wines. Food Res. Int. 2016, 82, 128-135. [CrossRef]

32. Vidal, L.; Antúnez, L.; Rodríguez-Haralambides, A.; Giménez, A.; Medina, K.; Boido, E.; Ares, G. Relationship between astringency and phenolic composition of commercial Uruguayan Tannat wines: Application of boosted regression trees. Food Res. Int. 2018, 112, 25-37. [CrossRef] [PubMed]

33. Casassa, L.F.; Larsen, R.C.; Harbertson, J.F. Effects of vineyard and winemaking practices impacting berry size on evolution of phenolics during winemaking. Am. J. Enol. Vitic. 2016, 67, 257-268. [CrossRef]

34. Ristic, R.; Bindon, K.; Francis, L.I.; Herderich, M.J.; Iland, P.G. Flavonoids and $\mathrm{C}_{13}$-norisoprenoids in Vitis vinifera L. cv. Shiraz: Relationships between grape and wine composition, wine colour and wine sensory properties. Aust. J. Grape Wine Res. 2010, 16, 369-388. [CrossRef]

35. Singleton, V.L.; Rossi, J.A. Colorimetry of total phenolics with phosphomolybdic-phosphotungstic acid reagents. Am. J. Enol. Vitic. 1965, 16, 144-158.

36. Zarrouk, O.; Francisco, R.; Pinto-Marijuan, M.; Brossa, R.; Santos, R.R.; Pinheiro, C.; Costa, J.M.; Lopes, C.; Chaves, M.M. Impact of irrigation regime on berry development and flavonoids composition in Aragonez (Syn. Tempranillo) grapevine. Agric. Water Manag. 2012, 114, 18-29. [CrossRef]

37. Pastrana-Bonilla, E.; Akoh, C.C.; Sellappan, S.; Krewer, G. Phenolic content and antioxidant capacity of Muscadine grapes. J. Agric. Food Chem. 2003, 51, 5497-5503. [CrossRef] [PubMed]

38. Breksa, A.P.; Takeoka, G.R.; Hidalgo, M.B.; Vilches, A.; Vasse, J.; Ramming, D.W. Antioxidant activity and phenolic content of 16 raisin grape (Vitis vinifera L.) cultivars and selections. Food Chem. 2010, 121, 740-745. [CrossRef]

39. Deshpande, S.S.; Cheryan, M.; Salunkhe, D.K.; Luh, B.S. Tannin analysis of food products. Crit. Rev. Food Sci. Nutr. 1986, 24, 401-449. [CrossRef]

40. Sun, B.; Ricardo-da-Silva, J.M.; Spranger, I. Critical factors of vanillin assay for catechins and proanthocyanidins. J. Agric. Food Chem. 1998, 46, 4267-4274. [CrossRef]

41. Mc Murrough, I.; McDowell, J. Chromatographic separation and automated analysis of flavanols. Anal. Biochem. 1978, 100, 91-92.

42. Nagel, C.W.; Glories, Y. Use of a modified dimethylaminocinnamaldehyde reagent for analysis of flavanols. Am. J. Enol. Vitic. 1991, 42, 364-366.

43. Versari, A.; Toiu, W.; Parpinello, G.P. Oenological tannins: A review. Aust. J. Grape Wine Res. 2013, 19, 1-10. [CrossRef]

44. Hagerman, A.E.; Butler, L.G. Protein precipitation method for the quantitative determination of tannins. J. Agric. Food Chem. 1978, 26, 809-812. [CrossRef]

45. Harbertson, J.F.; Kennedy, J.A.; Adams, D.O. Tannin in skins and seeds of Cabernet Sauvignon, Syrah, and Pinot noir berries during ripening. Am. J. Enol. Vitic. 2002, 53, 54-59.

46. Carvalho, E.; Mateus, N.; De Freitas, V.A.P. Flow nephelometric analysis of protein-tannin interactions. Anal. Chim. Acta 2004, 513, 97-101. [CrossRef] 
47. Glories, Y. Characteristics of the various constitutive fractions of the phenolic compounds in red wine and their oenological properties. Ann. Technol. Agric. 1978, 27, 253-255.

48. Edelmann, A.; Lendl, B. Toward the optical tongue: Flow-through sensing of tannin-protein interactions based on FTIR spectroscopy. J. Am. Chem. Soc. 2002, 124, 14741-14747. [CrossRef]

49. Goldner, M.C.; Zamora, M.C. Effect of polyphenol concentrations on astringency perception and its correlation with gelatin index of red wine. J. Sens. Stud. 2010, 25, 761-777. [CrossRef]

50. Delgado, R.; Martín, P.; del Álamo, M.; González, M.R. Changes in the phenolic composition of grape berries during ripening in relation to vineyard nitrogen and potassium fertilisation rates. J. Sci. Food Agric. 2004, 84, 623-630. [CrossRef]

51. Sarni-Manchado, P.; Cheynier, V.; Moutounet, M. Interactions of Grape Seed Tannins with Salivary Proteins. J. Agric. Food Chem. 1999, 47, 42-47. [CrossRef] [PubMed]

52. Sarneckis, C.J.; Dambergs, R.G.; Jones, P.; Mercurio, M.D.; Herderich, M.J.; Smith, P.A. Quantification of condensed tannins by precipitation with methyl cellulose: Development and validation of an optimised tool for grape and wine analysis. Aust. J. Grape Wine Res. 2006, 12, 39-49. [CrossRef]

53. Mercurio, M.D.; Smith, P.A. Tannin quantification in red grapes and wine: Comparison of polysaccharide- and protein-based tannin precipitation techniques and their ability to model wine astringency. J. Agric. Food Chem. 2008, 56, 5528-5537. [CrossRef] [PubMed]

54. Glories, Y.; Augustin, M. Maturité Phénolique du Raisin, Conséquences Technologiques: Application Aux Millésimes 1991 et $1992 ;$ CR Colloque Journée Techn; CIVB: Bordeaux, France, 1993; pp. 56-61.

55. Saint-Cricq, N.; Vivas, N.; Glories, Y. Maturité phénolique: Définition et côntrole. Rev. Fr. Oenol. 1998, $173,22-25$.

56. Ribéreau-Gayon, P.; Stonestreet, E. Le dosage des anthocyanes dans les vins rouges. Bull. Soc. Chim. 1965, 9, $2649-2651$.

57. Ribéreau-Gayon, P.; Stonestreet, E. Dosage des tannins dans les vins rouges et determination de leur structure. Chim. Anal. 1966, 48, 188-196.

58. Nadal, M. Phenolic maturity in red grapes. In Methodologies and Results in Grapevine Research; Del Rot, S., Or, E., Grando, S., Medrano, H., Bavaresco, L., Eds.; Springer Science + Business Media: Dordrecht, The Netherland; Berlin/Heidelberg, Germany; London, UK; New York, NY, USA, 2011; pp. 389-409.

59. Peyron, D. Le potentiel phénolique du pinot noir. Rev. Fr. Oenol. 1998, 170, 42-45.

60. Mateos, S. Determinació de la Maturesa Fenòlica en Varietats de Räim Negres; DEA, Universitat Rovira i Virgili: Tarragona, Spain, 2003.

61. Lamadon, F. Protocole pour l'évaluation de la richesse phénolique des raisins. Rev. Enol. 1995, 76, 37-38.

62. Iland, P.; Bruer, N.; Edwards, G.; Weeks, S.; Wilkes, E. Chemical Analysis of Grapes and Wine: Techniques and Concepts; Patrick Iland Wine Promotions PTY Ltd.: Campbelltown, Australia, 2004.

63. Downey, M.O.; Hanlin, R.L. Comparison of ethanol and acetone mixtures for extraction of condensed tannin from grape skin. S. Afr. J. Enol.Vitic. 2010, 31, 154-159. [CrossRef]

64. Kennedy, J.A.; Jones, J.P. Analysis of proanthocyanidin cleavage products following acid-catalysis in the presence of excess phloroglucinol. J. Agric. Food Chem. 2001, 49, 1740-1746. [CrossRef]

65. Rigaud, J.; Perez-Ilzarbe, J.; Ricardo da Silva, J.M.; Cheynier, V. Micromethod for identification of proanthocyanidin using thiolysis monitored by high-performance liquid chromatography. J. Chromatogr. 1991, 40, 401-405. [CrossRef]

66. Souquet, J.M.; Cheynier, V.; Brossaud, F.; Moutounet, M. Polymeric proanthocyanidins from grape skins. Phytochemistry 1996, 43, 509-512. [CrossRef]

67. Kennedy, J.A.; Ferrier, J.; Harbertson, J.F.; Peyrot des Gachons, C. Analysis of tannins in red wine using multiple methods: Correlation with perceived astringency. Am. J. Enol. Vitic. 2006, 57, 481-485.

68. Du Toit, W.J.; Visagie, M. Correlations between South African red grape and wine colour and phenolic composition: Comparing the Glories, Iland and bovine serum albumin tannin precipitation methods. S. Afr. J. Enol. Vitic. 2012, 33, 33-41. [CrossRef]

69. Williams, V.M.; Porter, L.J.; Hemingway, R.W. Molecular weight profiles of proanthocyanidin polymers. Phytochemistry 1983, 22, 569-572. [CrossRef]

70. Cacho, J.; Castells, J.E. Fractionation of phenolic compounds from grapes by size exclusion liquid chromatography with HPLC instrumentation. Am. J. Enol. Vitic. 1991, 42, 327-335.

71. Kennedy, J.A.; Waterhouse, A.L. Analysis of pigmented high-molecular-mass grape phenolics using ion-pair, normal-phase high-performance liquid chromatography. J. Chrom. A 2000, 866, 25-34. [CrossRef]

72. Bakker, J.; Timberlake, C.F. The distribution of anthocyanins in grape skin extracts of port wine cultivars as determined by high performance liquid chromatography. J. Sci. Food Agric. 1985, 36, 1315-1324. [CrossRef]

73. Mattivi, F.; Guzzon, R.; Vrhovsek, U.; Stefanini, M.; Velasco, R. Metabolite profiling of grape: Flavonols and anthocyanins. J. Agric. Food Chem. 2006, 54, 7692-7702. [CrossRef] [PubMed]

74. Wulf, L.; Nagel, C. High-pressure liquid chromatographic separation of anthocyanins of Vitis vinifera. Am. J. Enol. Vitic. 1978, 29, $42-49$.

75. Roggero, J.P.; Coen, S.; Ragonnet, B. High performance liquid chromatography survey on changes in pigment content in ripening grapes of Syrah. An approach to anthocyanin metabolism. Am. J. Enol. Vitic. 1986, 37, 77-83.

76. Hebrero, E.; Santos-Buelga, C.; Rivas-Gonzalo, J.C. High performance liquid chromatography-diode array spectroscopy identification of anthocyanins of Vitis vinifera variety Tempranillo. Am. J. Enol. Vitic. 1988, 39, 227-233. 
77. Downey, M.O.; Mazza, M.; Krstic, M.P. Development of a stable extract for anthocyanins and flavonols from grape skin. Am. J. Enol. Vitic. 2007, 58, 358-364.

78. Spayd, S.E.; Tarara, J.M.; Mee, D.L.; Ferguson, J.C. Separation of sunlight and temperature effects on the composition of Vitis vinifera cv. Merlot berries. Am. J. Enol. Vitic. 2002, 53, 171-182.

79. Peyrot des Gachons, C.; Kennedy, J.A. Direct method for determining seed and skin proanthocyanidin extraction into red wine. J. Agric. Food Chem. 2003, 51, 5877-5881. [CrossRef] [PubMed]

80. González-Manzano, S.; Rivas-Gonzalo, J.C.; Santos-Buelga, C. Extraction of flavan-3-ols from grape seed and skin into wine using simulated maceration. Anal. Chim. Acta 2004, 513, 283-289. [CrossRef]

81. Mattivi, F.; Vrhovsek, U.; Masuero, D.; Trainotti, D. Differences in the amount and structure of extractable skin and seed tannins amongst red grape varieties. Aust. J. Grape Wine Res. 2009, 15, 27-35. [CrossRef]

82. Llaudy, M.C.; Canals, R.; Canals, J.M.; Zamora, F. Influence of ripening stage and maceration length on the contribution of grape skins, seeds and stems to phenolic composition and astringency in wine-simulated macerations. Eur. Food Res. Technol. 2008, 226, 337-344. [CrossRef]

83. Gambuti, A.; Capuano, R.; Lecce, L.; Fragasso, M.G.; Moio, L. Extraction of phenolic compounds from "Aglianico" and "Uva di Troia" grape skin and seeds in model solutions: Influence of ethanol and maceration time. Vitis 2009, 48, 193-200.

84. Allegro, G.; Pastore, C.; Valentini, G.; Muzzi, E.; Filippetti, I. Influence of berry ripeness on accumulation, composition and extractability of skin and seed flavonoids in cv. Sangiovese (V. vinifera L.). J. Sci. Food Agric. 2016, 96, 4553-4559. [CrossRef]

85. Bindon, K.; Kassara, S.; Cynkar, W.U.; Robinson, E.M.C.; Scrimgeour, N.; Smith, P.A. Comparison of extraction protocols to determine differences in wine-extractable tannin and anthocyanin in Vitis vinifera L. cv. Shiraz and Cabernet Sauvignon grapes. J. Agric. Food Chem. 2014, 62, 4558-4570. [CrossRef]

86. Río Segade, S.; Vásquez, E.S.; Losada, E.D. Influence of ripeness grade on accumulation and extractability of grape skin anthocyanins in different cultivars. J. Food Comp. Anal. 2008, 21, 599-607. [CrossRef]

87. Rolle, L.; Torchio, F.; Zeppa, G.; Gerbi, V. Relations between break skin force and anthocyanin extractability at different stages of ripening. Am. J. Enol. Vitic. 2009, 60, 93-97.

88. Torchio, F.; Cagnasso, E.; Gerbi, V.; Rolle, L. Mechanical properties, phenolic composition and extractability indices of Barbera grapes of different soluble solids contents from several growing areas. Anal. Chim. Acta 2010, 660, 183-189. [CrossRef]

89. Río Segade, S.; Giacosa, S.; Gerbi, V.; Rolle, L. Berry skin thickness as main texture parameter to predict anthocyanin extractability in winegrapes. LWT Food Sci. Technol. 2011, 44, 392-398. [CrossRef]

90. Cerovic, Z.G.; Moise, N.; Agati, G.; Latouche, G.; Ben Ghozlen, N.; Meyer, S. New portable optical sensors for the assessment of winegrape phenolic maturity based on berry fluorescence. J. Food Comp. Anal. 2008, 21, 650-654. [CrossRef]

91. Nogales-Bueno, J.; Hernández-Hierro, J.M.; Rodríguez-Pulido, F.J.; Heredia, F.J. Determination of technological maturity of grapes and total phenolic compounds of grape skins in red and white cultivars during ripening by near infrared hyperspectral image: A preliminary approach. Food Chem. 2014, 152, 586-591. [CrossRef] [PubMed]

92. Ristic, R.; Iland, P.G. Relationship between seed and berry development of Vitis vinifera L. cv. Shiraz: Developmental changes in seed morphology and phenolic composition. Aust. J. Grape Wine Res. 2005, 11, 43-58. [CrossRef]

93. Fredes, C.; Von Bennewitz, E.; Holzapfel, E.; Saavedra, F. Relation between seed appearance and phenolic maturity: A case study using grapes cv. Carménère. Chil. J. Agric. Res. 2010, 70, 381-389. [CrossRef]

94. Rodríguez-Pulido, F.J.; Ferrer-Gallego, R.; González-Miret, M.L.; Rivas-Gonzalo, J.C.; Escribano-Bailón, M.T.; Heredia, F.J. Preliminary study to determine the phenolic maturity stage of grape seeds by computer vision. Anal. Chim. Acta 2012, 732, 78-82. [CrossRef]

95. Avila, F.; Mora, M.; Fredes, C. A method to estimate grape phenolic maturity based on seed images. Comput. Electr. Agric. 2014, 101, 76-83. [CrossRef]

96. Teixeira, A.; Eiras-Dias, J.; Castellarin, S.D.; Gerós, H. Berry phenolics of grapevine under challenging environments. Int. J. Mol. Sci. 2013, 14, 18711-18739. [CrossRef] [PubMed]

97. Torres, N.; Martínez-Lüscher, J.; Porte, E.; Kurtural, S.K. Optimal ranges and thresholds of grape berry solar radiation for flavonoid biosynthesis in warm climates. Front. Plant Sci. 2020, 11, 931. [CrossRef]

98. Castellarin, S.D.; Di Gaspero, G.; Marconi, R.; Nonis, A.; Peterlunger, E.; Paillard, S.; Adam-Blondon, A.F.; Testolin, R. Colour variation in red grapevines (Vitis vinifera L.): Genomic organisation, expression of flavonoid $3^{\prime}$-hydroxylase, flavonoid $3^{\prime}, 5^{\prime}-$ hydroxylase genes and related metabolite profiling of red cyanidin-/blue delphinidin-based anthocyanins in berry skin. $B M C$ Genom. 2006, 7, 1-17. [CrossRef] [PubMed]

99. Mazza, G.; Francis, F.J. Anthocyanins in grapes and grape products. Crit. Rev. Food Sci. Nutr. 1995, 35, 341-371. [CrossRef]

100. Rinaldo, A.R.; Cavallini, E.; Jia, Y.; Moss, S.M.; McDavid, D.A.; Hooper, L.C.; Robinson, S.P.; Tornielli, G.B.; Zenoni, S.; Ford, C.M.; et al. A grapevine anthocyanin acyltransferase, transcriptionally regulated by VvMYBA, can produce most acylated anthocyanins present in grape skins. Plant Physiol. 2015, 169, 1897-1916. [CrossRef] [PubMed]

101. Bogs, J.; Downey, M.O.; Harvey, J.S.; Ashton, A.R.; Tanner, G.J.; Robinson, S.P. Proanthocyanidin synthesis and expression of genes encoding leucoanthocyanidin reductase and anthocyanidin reductase in developing grape berries and grapevines leaves. Plant Physiol. 2005, 139, 652-663. [CrossRef] [PubMed]

102. Kennedy, J.A.; Matthews, M.A.; Waterhouse, A.L. Changes in grape seed polyphenols during fruit ripening. Phytochemistry 2000, 55, 77-85. [CrossRef] 
103. Cadot, Y.; Miñana-Castello, M.T.; Chevalier, M. Anatomical, histological, and histochemical changes in grape seeds from Vitis vinifera L. cv. Cabernet franc during fruit development. J. Agric. Food Chem. 2006, 54, 9206-9215. [CrossRef]

104. De Freitas, V.A.P.; Glories, Y.; Monique, A. Developmental changes of procyanidins in grapes of red Vitis vinifera varieties and their composition in respective wines. Am. J. Enol. Vitic. 2000, 51, 397-403.

105. Katalinic, V.; Males, P. Compositional changes in grape phenols throughout maturation. J. Wine Res. 1997, 8, 169-177. [CrossRef]

106. Pastor Del Rio, J.L.; Kennedy, J.A. Development of proanthocyanidins in Vitis vinifera L. cv. Pinot noir grapes and extraction into wine. Am. J. Enol. Vitic. 2006, 57, 125-132.

107. Hanlin, R.L.; Downey, M.O. Condensed tannin accumulation and composition in skin of Shiraz and Cabernet Sauvignon grapes during berry development. Am. J. Enol. Vitic. 2009, 60, 13-23.

108. Kennedy, J.A.; Troup, G.J.; Pilbrow, J.R.; Hutton, D.R.; Hewitt, D.; Hunter, C.R.; Ristic, R.; Iland, P.G.; Jones, G.P. Development of seed polyphenols in berries from Vitis vinifera L. cv. Shiraz. Aust. J. Grape Wine Res. 2000, 6, 244-254. [CrossRef]

109. Bordiga, M.; Travaglia, F.; Locatelli, M.; Coïsson, J.D.; Arlorio, M. Characterisation of polymeric skin and seed proanthocyanidins during ripening in six Vitis vinifera L. cv. Food Chem. 2011, 127, 180-187. [CrossRef]

110. Obreque-Slier, E.; López-Solís, R.; Castro-Ulloa, L.; Romero-Díaz, C.; Peña-Neira, A. Phenolic composition and physicochemical parameters of Carménère, Cabernet Sauvignon, Merlot and Cabernet Franc grape seeds (Vitis vinifera L.) during ripening. LWT Food Sci. Technol. 2012, 48, 134-141. [CrossRef]

111. Mucalo, A.; Maletić, E.; Zdunić, G. Extended harvest date alter flavonoid composition and chromatic characteristics of Plavac Mali (Vitis vinifera L.) grape berries. Foods 2020, 9, 1155. [CrossRef] [PubMed]

112. Kennedy, J.A.; Hayasaka, Y.; Vidal, S.; Waters, E.J.; Jones, J.P. Composition of grape skin proanthocyanidins at different stages of berry development. J. Agric. Food Chem. 2001, 49, 5348-5355. [CrossRef] [PubMed]

113. Kennedy, J.A.; Matthews, M.A.; Waterhouse, A.L. Effect of maturity and vine water status on grape skin and wine flavonoids. Am. J. Enol. Vitic. 2002, 53, 268-274.

114. Bindon, K.; Varela, C.; Kennedy, J.A.; Holt, H.; Herderich, M. Relationships between harvest time and wine composition in Vitis vinifera L. Food Chem. 2013, 138, 1696-1705. [CrossRef]

115. Bindon, K.A.; Hadi Madani, S.; Pendelton, P.; Smith, P.A.; Kennedy, J.A. Factors affecting skin tannin extractability in ripening grapes. J. Agric. Food Chem. 2014, 62, 1130-1141. [CrossRef]

116. Holt, H.E.; Birchmore, W.; Herderich, M.J.; Iland, P.G. Berry phenolics in Cabernet Sauvignon (Vitis vinifera L.) during late-stage ripening cv. Cabernet Sauvignon 1. Grape and wine chemistry. Am. J. Enol. Vitic. 2010, 61, 285-299.

117. Canals, R.; Llaudy, M.C.; Valls, J.; Canals, J.M.; Zamora, F. Influence of ethanol concentration on the extraction of color and phenolic compounds from the skin and seeds of Tempranillo grapes at different stages of ripening. J. Agric. Food Chem. 2005, 53, 4019-4025. [CrossRef] [PubMed]

118. Hernández-Hierro, J.M.; Quijada-Morín, N.; Rivas-Gonzalo, J.C.; Escribano-Bailón, M.T. Influence of the physiological stage and the content of soluble solids on the anthocyanin extractability of Vitis vinifera L. cv. Tempranillo grapes. Anal. Chim. Acta 2012, 732, 26-32. [CrossRef]

119. Bindon, K.; Holt, H.; Williamson, P.O.; Varela, C.; Herderich, M.; Francis, I.L. Relationships between harvest time and wine composition in Vitis vinifera L. cv. Cabernet Sauvignon 2. Wine sensory properties and consumer preference. Food Chem. 2014, 154, 90-101. [CrossRef] [PubMed]

120. Obreque-Slier, E.; Peña-Neira, A.; López-Solís, R.; Zamora-Martín, F.; Ricardo da Silva, J.; Laureano, O. Comparative study of the phenolic composition of seeds and skins from Carménère and Cabernet Sauvignon grape varieties (Vitis vinifera L.) during ripening. J. Agric. Food Chem. 2010, 58, 3591-3599. [CrossRef]

121. Bautista-Ortín, A.B.; Fernández-Fernández, J.I.; López-Roca, J.M.; Gómez-Plaza, E. The effect of grape ripening stage on red wine color. J. Int. Sci. Vigne Vin 2006, 40, 15-24. [CrossRef]

122. Nunan, K.J.; Sims, I.M.; Bacic, A.; Robinson, S.P.; Fincher, G.B. Changes in cell wall composition during ripening of grape berries. Plant Physiol. 1998, 118, 783-792. [CrossRef] [PubMed]

123. Bautista-Ortín, A.B.; Rodríguez-Rodríguez, P.; Gil-Muñoz, R.; Jiménez Pasqual, E.; Busse-Valverde, N.; Martínez-Cutillas, A.; López-Roca, J.M.; Gómez-Plaza, E. Influence of berry ripeness on concentration, qualitative composition and extractability of grape seed tannins. Aust. J. Grape Wine Res. 2012, 18, 123-130. [CrossRef]

124. Nunan, K.J.; Sims, I.M.; Bacic, A.; Robinson, S.P.; Fincher, G.B. Isolation and characterization of cell walls from the mesocarp of mature grape berries (Vitis vinifera). Planta 1997, 203, 93-100.

125. Ortega-Regules, A.; Ros-García, J.M.; Bautista-Ortín, A.B.; López-Roca, J.M.; Gómez-Plaza, E. Changes in skin cell wall composition during the maturation of four premium wine grape varieties. J. Sci. Food Agric. 2008, 88, 420-428. [CrossRef]

126. Hanlin, R.L.; Hrmova, M.; Harbertson, J.F.; Downey, M.O. Review: Condensed tannin and grape cell wall interactions and their impact on tannin extractability into wine. Aust. J. Grape Wine Res. 2010, 16, 173-178. [CrossRef]

127. Vidal, S.; Williams, P.; O'Neill, M.A.; Pellerin, P. Polysaccharides from grape berry cell walls. Part I: Tissue distribution and structural characterization of the pectic polysaccharides. Carbohydr. Polym. 2001, 45, 315-323. [CrossRef]

128. Huang, X.-M.; Huang, H.-B.; Wong, H.C. Cell walls of loosening skin in post-veraison grape berries lose structural polysaccharides and calcium while accumulate structural proteins. Sci. Hort. 2005, 104, 249-263. [CrossRef] 
129. Vicens, A.; Fournand, D.; Williams, P.; Sidhoum, L.; Moutounet, M.; Doco, T. Changes in polysaccharide and protein composition of cell walls in grape berry skin (Cv. Shiraz) during ripening and over-ripening. J. Agric. Food Chem. 2009, 57, 2955-2960. [CrossRef] [PubMed]

130. Le Bourvellec, C.; Guyot, S.; Renard, C.M.G.C. Non-covalent interaction between procyanidins and apple cell wall material. Part, I. Effect of some environmental parameters. Biochim. Biophys. Acta 2004, 1672, 192-202. [CrossRef] [PubMed]

131. Osete-Alcaraz, A.; Bautista-Ortín, A.B.; Gómez-Plaza, E. The role of soluble polysaccharides in tannin-cell wall interactions in model solutions and in wines. Biomolecules 2020, 10, 36. [CrossRef] [PubMed]

132. Le Bourvellec, C.; Bouchet, B.; Renarda, C.M.G.C. Non-covalent interaction between procyanidins and apple cell wall material. Part III: Study on model polysaccharides. Biochim. Biophys. Acta 2005, 1725, 10-18. [CrossRef]

133. Ruiz-Garcia, Y.; Smith, P.A.; Bindon, K.A. Selective extraction of polysaccharide affects the adsorption of proanthocyanidin by grape cell walls. Carbohydr. Polym. 2014, 114, 102-114. [CrossRef]

134. Le Bourvellec, C.; Renarda, C.M.G.C. Non-covalent interaction between procyanidins and apple cell wall material. Part II: Quantification and impact of cell wall drying. Biochim. Biophys. Acta 2005, 1725, 1-9. [CrossRef]

135. Bautista-Ortín, A.B.; Ruiz-García, Y.; Marín, F.; Molero, N.; Apolinar-Valiente, R.; Gómez-Plaza, E. Remarkable proanthocyanidin adsorption properties of Monastrell pomace cell wall material highlight its potential use as an alternative fining agent in red wine production. J. Agric. Food Chem. 2015, 63, 620-633. [CrossRef]

136. Haslam, E. Molecular Recognition-Phenols and Polyphenols. In Practical Polyphenolics: From Structure to Molecular Recognition and Physiological Action; Cambridge University Press: Cambridge, UK, 1998; pp. 138-177.

137. De Freitas, V.; Mateus, N. Structural features of procyanidin interactions with salivary proteins. J. Agric. Food Chem. 2001, 49, 940-945. [CrossRef]

138. Bautista-Ortín, A.B.; Cano-Lechuga, M.; Ruiz-García, J.; Gómez-Plaza, E. Interactions between grape skin cell wall material and commercial enological tannins. Practical implications. Food Chem. 2014, 152, 558-565. [CrossRef]

139. Bindon, K.A.; Smith, P.A.; Kennedy, J.A. Interaction between grape-derived proanthocyanidins and cell wall material. 1 . Effect on proanthocyanidin composition and molecular mass. J. Agric. Food Chem. 2010, 58, 2520-2528. [CrossRef] [PubMed]

140. Bindon, K.A.; Smith, S.; Smith, P.A. Towards a model of grape tannin extraction under wine-like conditions: The role of suspended mesocarp material and anthocyanin concentration. Aust. J. Grape Wine Res. 2017, 23, 22-32. [CrossRef]

141. Bindon, K.A.; Smith, P.A.; Holt, H.; Kennedy, J.A. Interaction between grape-derived proanthocyanidins and cell wall material. 2. Implications for vinification. J. Agric. Food Chem. 2010, 58, 10736-10746. [CrossRef] [PubMed]

142. Bindon, K.A.; Kennedy, J.A. Ripening-induced changes in grape skin proanthocyanidins modify their interaction with cell walls. J. Agric. Food Chem. 2011, 59, 2696-2707. [CrossRef]

143. Bindon, K.A.; Bacic, A.; Kennedy, J.A. Tissue-specific and developmental modifications of grape cell walls influence the adsorption of proanthocyanidins. J. Agric. Food Chem. 2012, 60, 9249-9260. [CrossRef]

144. Allegro, G.; Bautista-Ortín, A.B.; Gómez-Plaza, E.; Pastore, C.; Valentini, G.; Filippetti, I. Impact of flavonoid and cell wall material changes on phenolic maturity in cv. Merlot (Vitis vinifera L.). Am. J. Enol. Vitic. 2018, 69, 417-421. [CrossRef]

145. Castro-López, L.; Gómez-Plaza, E.; Ortega-Regules, A.; Lozada, D.; Bautista-Ortín, A.B. Role of cell wall deconstructing enzymes in the proanthocyanidin-cell wall adsorption-desorption phenomena. Food Chem. 2016, 196, 526-532. [CrossRef]

146. Bindon, K.A.; Li, S.; Kassara, S.; Smith, P. Retention of proanthocyanidin in wine-like solution is conferred by a dynamic interaction between soluble and insoluble grape cell wall components. J. Agric. Food Chem. 2016, 64, 8406-8419. [CrossRef]

147. Padayachee, A.; Netzel, G.; Netzel, M.; Day, L.; Zabaras, D.; Mikkelsen, D.; Gidley, M.J. Binding of polyphenols to plant cell wall analogues-Part 1: Anthocyanins. Food Chem. 2012, 134, 155-161. [CrossRef]

148. Hernández-Hierro, J.M.; Quijada-Morín, N.; Martínez-Lapuente, L.; Guadalupe, Z.; Ayestarán, B.; Rivas-Gonzalo, J.C.; EscribanoBailón, M.T. Relationship between skin cell wall composition and anthocyanin extractability of Vitis vinifera L. cv. Tempranillo at different grape. Food Chem. 2014, 146, 41-47. [CrossRef] [PubMed]

149. Ortega-Regules, A.; Romero-Cascales, I.; Ros-García, J.M.; López-Roca, J.M.; Gómez-Plaza, E. A first approach towards the relationship between grape skin cell-wall composition and anthocyanin extractability. Anal. Chim. Acta 2006, 563, 26-32. [CrossRef]

150. Romero-Cascales, I.; Ortega-Regules, A.; López-Roca, J.M.; Férnandez-Férnandez, J.I.; Gómez-Plaza, E. Differences in anthocyanin extractability from grapes to wines according to variety. Am. J. Enol. Vitic. 2005, 56, 212-219.

151. Ortega-Regules, A.; Ros-García, J.M.; Bautista-Ortín, A.B.; López-Roca, J.M.; Gómez-Plaza, E. Differences in morphology and composition of skin and pulp cell walls from grapes (Vitis vinifera L.): Technological implications. Eur. Food Res. Tecnol. 2008, 227, 223-231. [CrossRef]

152. Bautista-Ortín, A.B.; Martínez-Hernández, A.; Ruiz-García, Y.; Gil-Muñoz, R.; Gómez-Plaza, E. Anthocyanins influence tannin-cell wall interactions. Food Chem. 2016, 206, 239-248. [CrossRef] [PubMed] 